\title{
Geotechnical Site Characterization of a Mud Eruption Disaster Area Using CPTu for Risk Assessment and Mitigation (IPL-195)
}

\author{
Paulus P. Rahardjo, Adityaputera Wirawan, and Andy Sugianto
}

\begin{abstract}
A mud eruption in East Java that occured on May 29, 2006 is well known worldwide. The mechanisms of the causes of the eruptions are still in debate, whether it was triggered by gas well drilling or by pressurised fluid reactivated by the Jogjakarta earthquake of May 26, 2006. This debate is not the main issue in this report. Instead, this paper discusses mainly the results of CPTu tests recently conducted and mitigation and risk reduction. The volume of the mud discharge is estimated at $5000 \mathrm{~m}^{3}$. Dykes were constructed to contain the mud, which covered areas reaching 650 ha (Sofyan 2015). The location of the disaster is in the middle of the town of Porong in the district of Sidoardjo, near Surabaya International airport, and mud has blocked the major arterial roads from north to south of East Java. The soil condition of the site is deep soft clays which causes instability of the dykes. Some dyke failures occurred, endangering residential areas due to the flow of the mud (Rahardjo 2015). This paper describes the characterics of the soil conditions from a number of drillings and $\mathrm{CPTu}$ tests conducted by the authors for designing the replacement of the arterial road and for dyke reinforcement, and also in the middle of the mud. The paper discuss the geotechnical problems of land subsidence over large areas and differential settlement that cause damage to infrastructure, including roads, gas pipes, railways, bridges and buildings, and is of particular importance to the safety of the dykes. The mud has been discharged through the Porong River, and sedimentation is part of the problem.
\end{abstract}

\section{Keywords}

Mud eruption $•$ Soft soils $\bullet$ Geotechnical failures $\bullet$ Land subsidence $\bullet$ CPTu $\bullet$ Mitigation and risk reduction

P.P. Rahardjo $(\bowtie) \cdot$ A. Wirawan · A. Sugianto

Universitas Katolik Parahyangan, Jl. Ciumbuleuit No. 94,

Bandung, 40142, Indonesia

e-mail: rahardjo.paulus@gmail.com

A. Wirawan

e-mail: teknik@gec.co.id 


\section{Introduction}

The mud disaster that occurred in 2006 in east Java is a special event that is very rare. A mud eruption occured on May 29, 2006 and is the biggest of its kind in the world. It was preceded by drilling for gas exploration in this area. However, until this day, there is still some speculation about whether the eruption was triggered by the drilling or by the Jogjakarta earthquake of May 26, 2006. It is still debated, but in recent discussions (Rahardjo 2015) Massini et al. (2010) claimed that there is a trend toward the opinion that the cause of the eruption is largely natural.

The disaster caused 14 fatalities, displaced 30,000 people (13,000 families), closed 30 factories and hundreds of small business, and flooded more than 10,000 homes with mud in more than a dozen villages (BPLS 2007). The team of Universitas Katolik Parahyangan (Unpar) has conducted a number of cone penetration tests using a piezocone with pore pressure sensors (CPTu) during the construction of the relocated arterial road to the west side and also in the area of the mud eruption and a nearby control dyke. This paper mainly deals with the geotechnical site characterization of the area using CPTu and the discussion of mitigation and risk reduction, which is the concern of the government. The location of this mud eruption is at Porong, the southern district of Sidoardjo regency, about $12 \mathrm{~km}$ south of the town of Sidoardjo. Figure 1 shows the location of the mud eruption.

The site is a residential area and surrounded by an industrial area in East Java. The Surabaya Gempol toll
Fig. 1 Location of the mud eruption in East Java, Indonesia

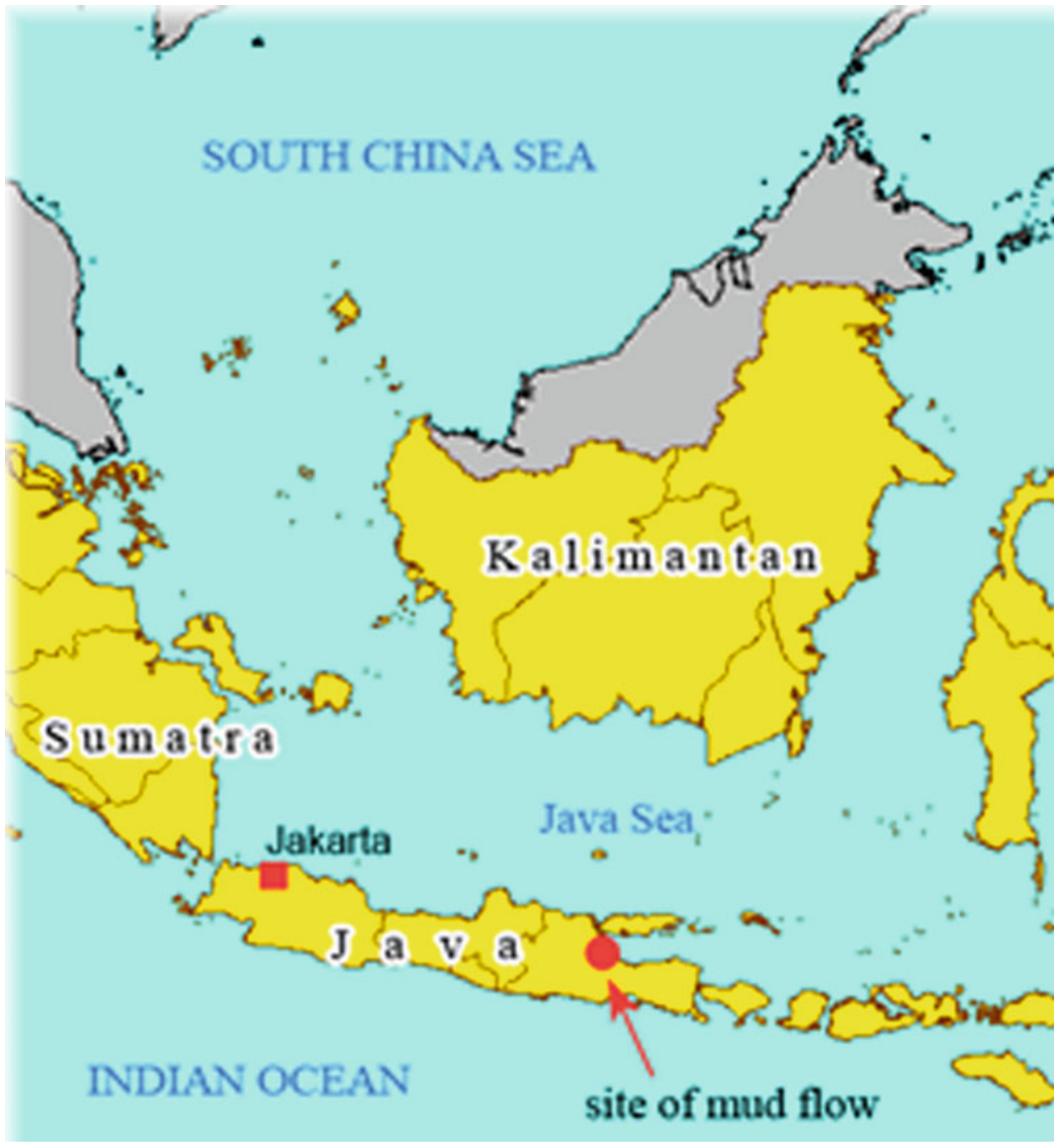




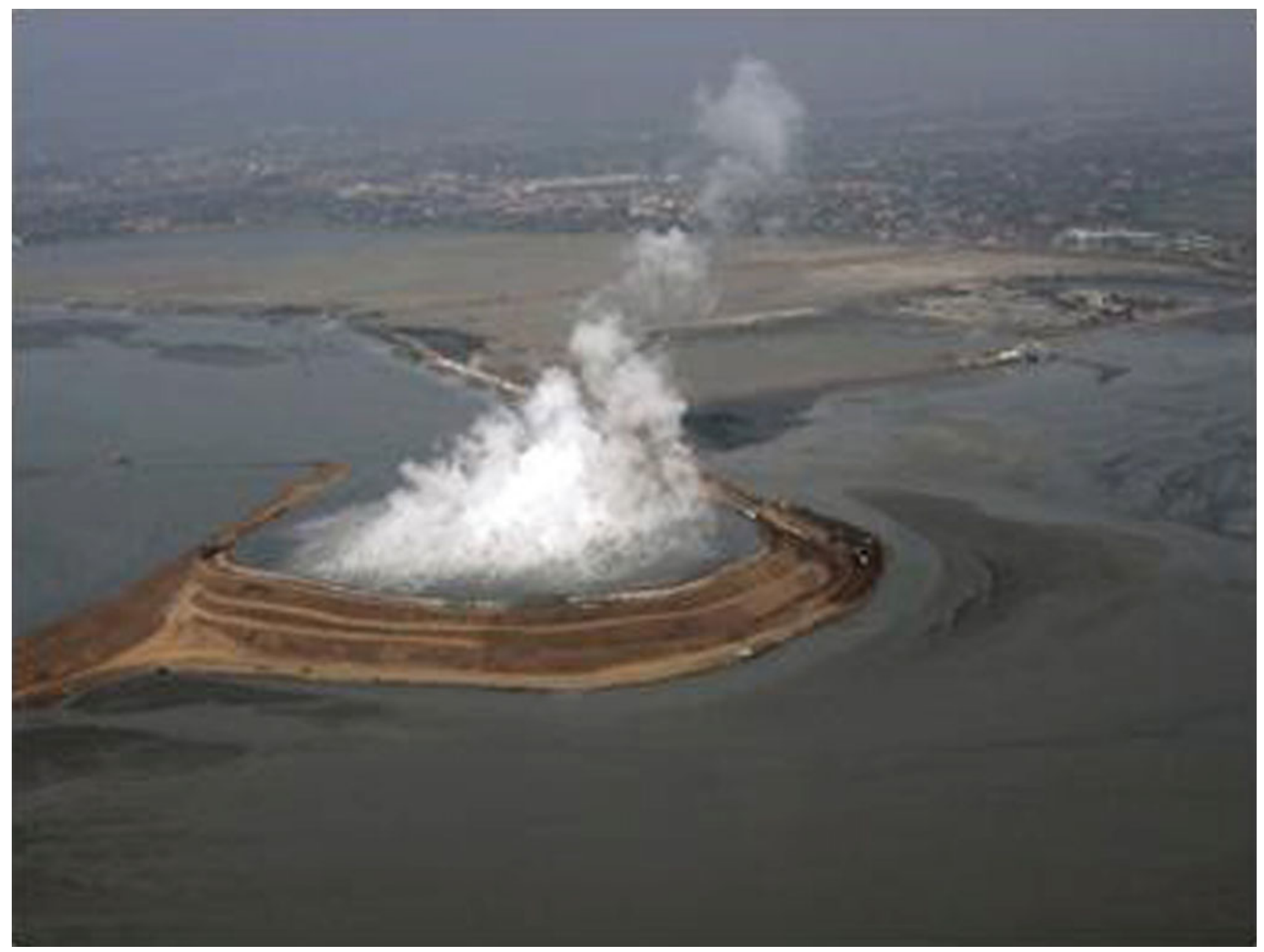

Fig. 2 The vent of the mud eruption in East Java, Indonesia, surrounded by protection dykes (Boston.com 2008)

highway Surabaya-Malang-Pasuruan Banyuwangi, which is an important economic route in East Java, is directly influenced by this mud eruption.

Despite of many efforts carried out to reduce the eruption, the scale of the disaster is beyond the capability of human beings. As a result, the last effort is merely defence to save the lives of people by containing the mud in cells and to limit the widening effect to the surrounding by pumping the mud into the Porong River.

The disaster has become the world's most destructive mud volcano (Wayman 2011). But at present, after almost 9 years, the discharge has dropped in volume, and this gives hope that the eruption is almost over. Some geologists however predicted that the flow of mud will end 30 years from the start of the disaster, so it seems that it is not certain and only a rather hasty conclusion.

The mud ejected through this volcano is hot, and for samples collected nearby, temperatures are in the range of 80-90 ${ }^{\circ} \mathrm{C}$ (Figs. 2, 3 and 4).

\section{The Cause of the Mud Eruption}

Prior to the mud eruption, there was drilling for gas exploration by a company in Indonesia, known as Banjar Panji 1 (Fig. 5), which had reached about $3000 \mathrm{~m}$ depth. Richard 


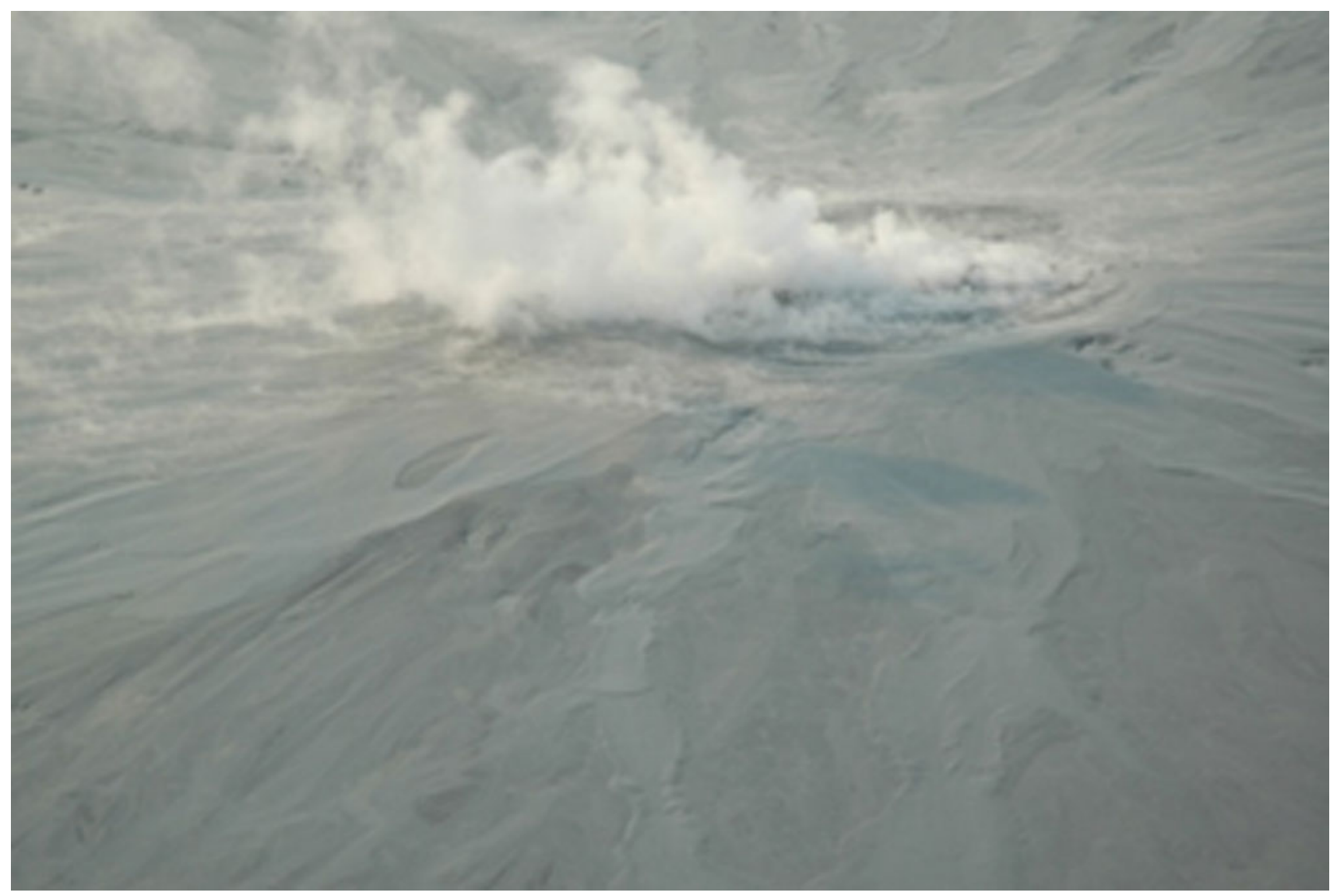

Fig. 3 The center of the mud eruption (BPLS 2007)

Davis, a geologist at Durham University in England believes that the gas released by the drilling, created failure in the surrounding rock, with materials being washed out to the surface. Figure 6 shows the mechanism, as illustrated in National Geographic magazine (2006). Michael Manga, a geologist at the University of California Berkeley, explained the overlying sediments compress the lower layers and pressure builds as the upper layers get thicker and heavier, and the squeezed water has no where to go. If a path to the surface opens, the highly pressurized water will shoot up (article rewritten by Wayman 2011).

However some other opinions, such as that of Adriano Mazzini of the University of Oslo, have suggested the occurrence was reactivation of the fault nearby due to the Yogyakarta shallow earthquake of magnitude $\mathrm{M}=6.3$ which was also believed to have reactivated the Opak Fault from the south of Yogjakarta to Central Java near Prambanan Temple. Stephen Miller, a geophysicist at the University of Bonn who led research on seismic energy from the quake, suggested it was reflected and focused by the surrounding rocks and became sufficiently concentrated to liquefy the mud source. According to the study, the mud fluid then injected itself into the adjacent Watukosek Fault (Fig. 7) and caused it to slip, thus linking it to a hydrothermal volcanic system deeper down, so that the previously trapped system completely rearranged itself and, fatally, became connected to the surface. Then the mud came.

Since 8 April 2010, there have been dramatic changes. The old Lusi crater (active since May 29, 2006) has died. The current speed of the flow at minimum conditions is 


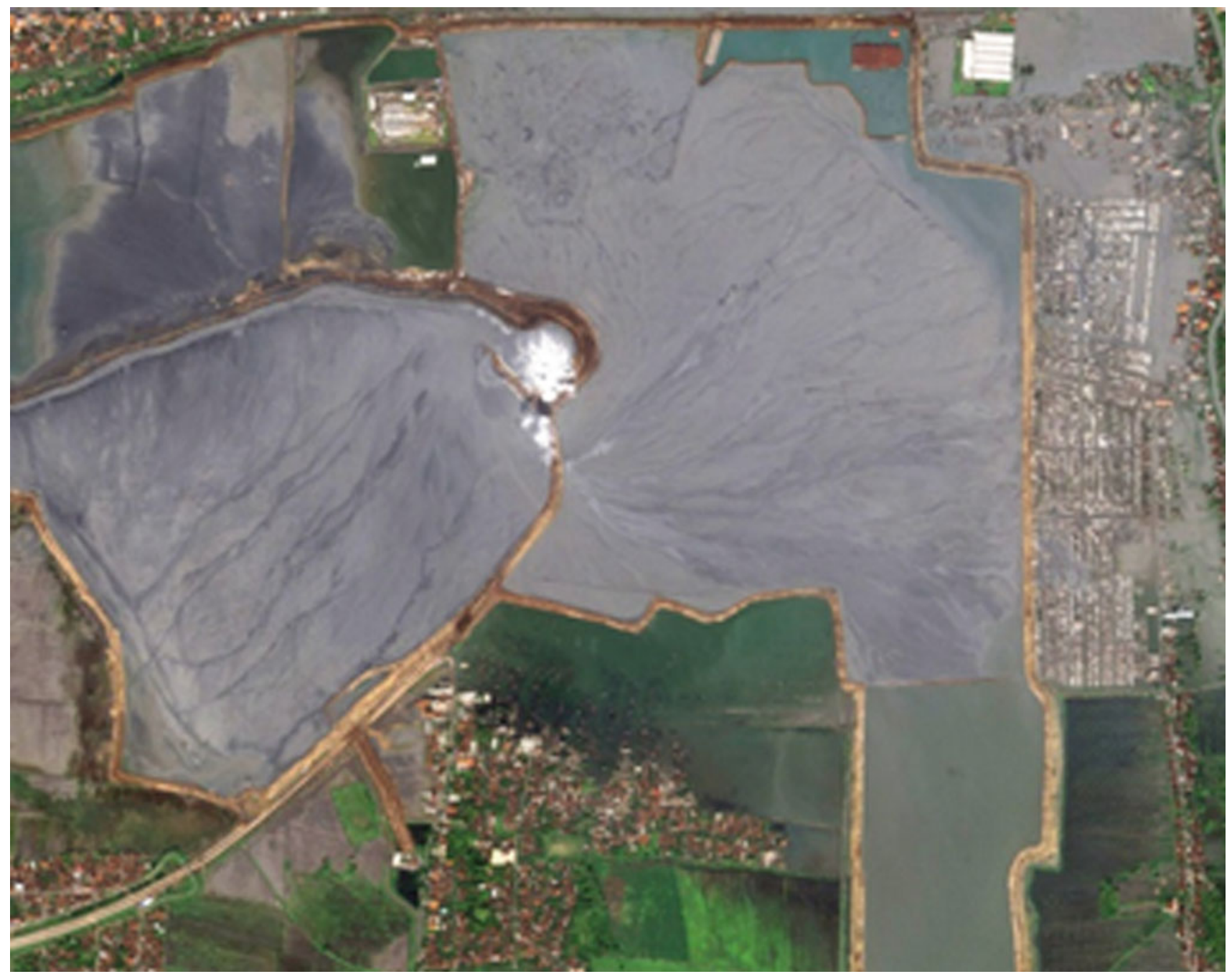

Fig. 4 The spreading of the mud eruption in the district of Sidoardjo and the cells with protection dykes (CRISP)

generally $<5000 \mathrm{~m}^{3}$ a day, compared to the peak rate at the beginning of $180,0000 \mathrm{~m}^{3} /$ day decreasing to around $100,000 \mathrm{~m}^{3}$ in $2008 / 2009$. Currently the model of Lusi Volcano is very much similar to Bledug Kuwu (in Central Java), with a kick of mud without flow or waves (Hady Prasetyo 2010).

\section{Characteristics of the Mud and Mud Removal}

The mud is very soft, consisting of about $70 \%$ water, with the material being clayey silts and very fine sands with gravel. This mud is difficult to handle because of its high liquidity and it cannot be easily removed except by mud pump (Rahardjo 2015). Figures 8 and 9 show the mud characteristics in wet and in drying conditions. After it is sufficiently mixed with water, the mud is pumped to the river, which in turn may cause other problems with sedimentation (see Fig. 10). This has caused environmental problems along the river and at the estuary, where a lot of sediment can not flow freely.

\section{Damage Due to the Mud Eruption}

The main damage to infrastructure is mainly due to mud flooding thousands of buildings, including houses, schools, mosques, and 30 factories, and damage to the toll roads of 


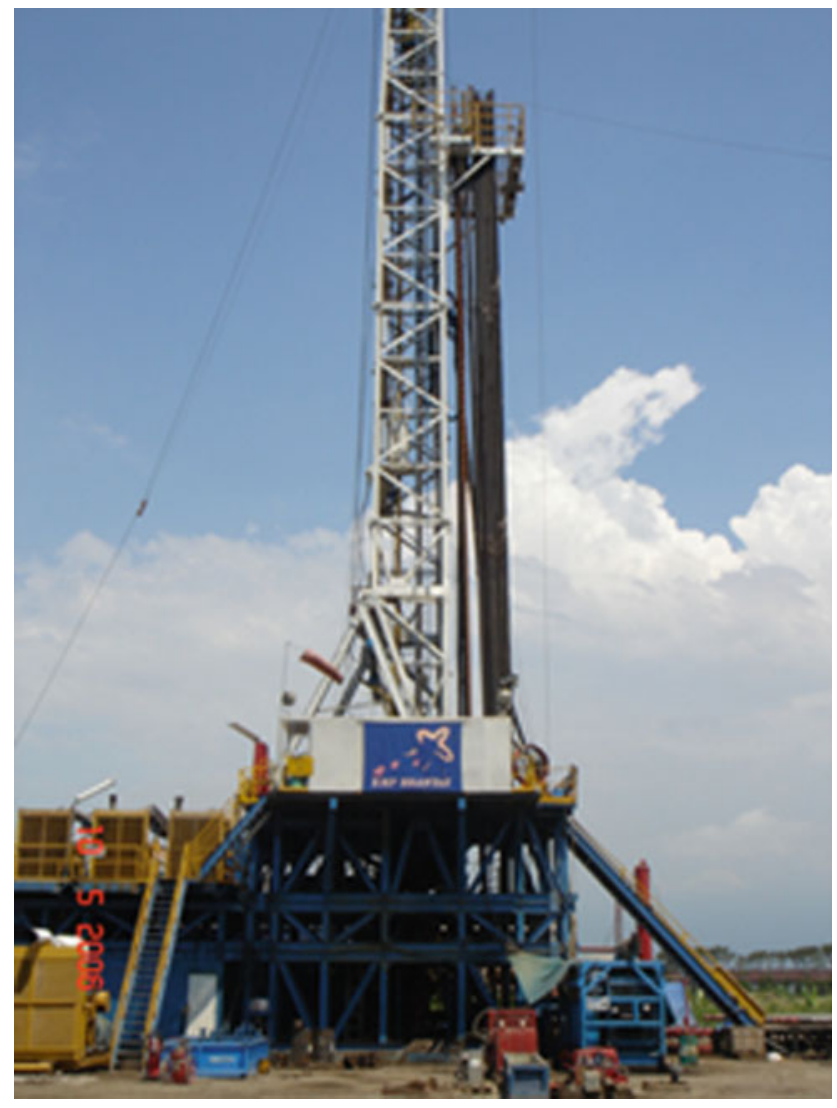

Fig. 5 Photograph of Banjar Panji 1 well (Didiek Djarwadi 2015)

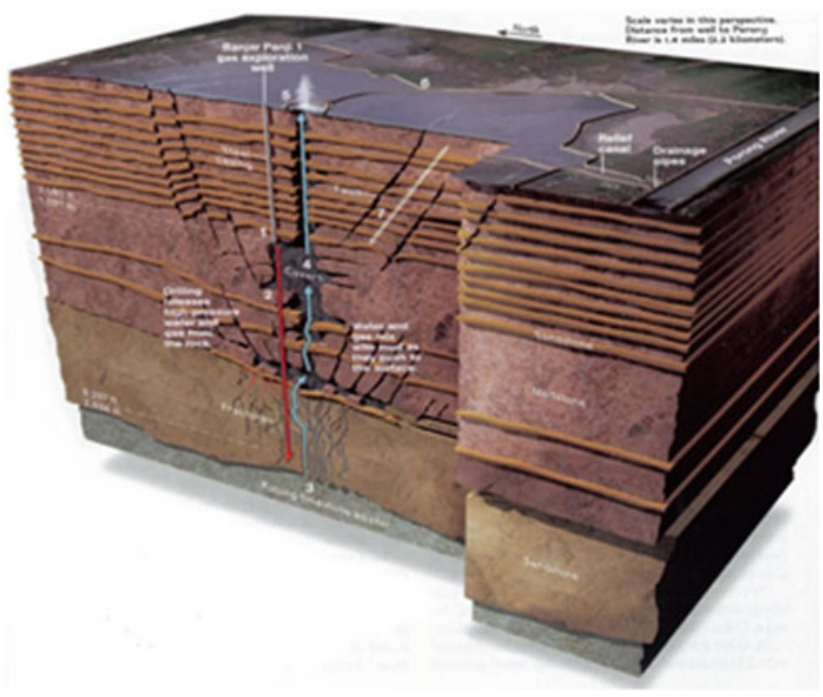

Fig. 6 The mechanism of the start of mud eruption (National Geographic 2006)
Surabaya-Gempol, Arterial Road Surabaya-Malang, and to railways, gas pipes, drainage canals and others structures, causing economic losses in the order of billions of US dollars. Both economic and social activities are significantly direct or indirectly affected.

Figure 11 shows the range of spreading of the mud in 2007, when the highway of Surabaya-Gempol was still in use. The author reviewed the condition of the dyke, and water had started seeping at the toe of the slope, which meant that the dyke was not safe. In the same year, this highway was flooded by the mud and is no longer used (Rahardjo 2015).

\section{Geotechnical Site Characterization Using CPTu}

\section{Soil Conditions at the Site}

Based on laboratory tests in this area, the soils are highly plastic materials, with a natural water content ranging from $40-100 \%$. Generally the upper part is slightly stronger, showing slight overconsolidation. However the void ratio could be as high as 1.5-3.0. Laboratory tests also show that the soft soils are still consolidating. Compressibility of the soils, measured by its compression index is very high, with a range of 0.5-1.5, so the settlement is large (Soleman 2012) (Fig. 12).

Based on in situ testing (CPTu and SPT), the soil upper layers are very soft, with a thickness of 15-25 m, dominated by clays to silts and silty sands. The silty sands are mixed with clay. This soil condition has a very low bearing capacity and may cause very substantial settlement upon loading. The possibility of squeezing of lower soil layers are among the problems that need to be considered.

\section{CPTu Tests at the Mud Site}

The use of CPTu (Cone Penetration Test with pore pressure measurement) has been popular in Indonesia since 1990, especially for soft soils. The increasing use of the CPTu is due to a number of factors:

- It is handy, fast and accurate for soil profiling and not dependent on the operators. 


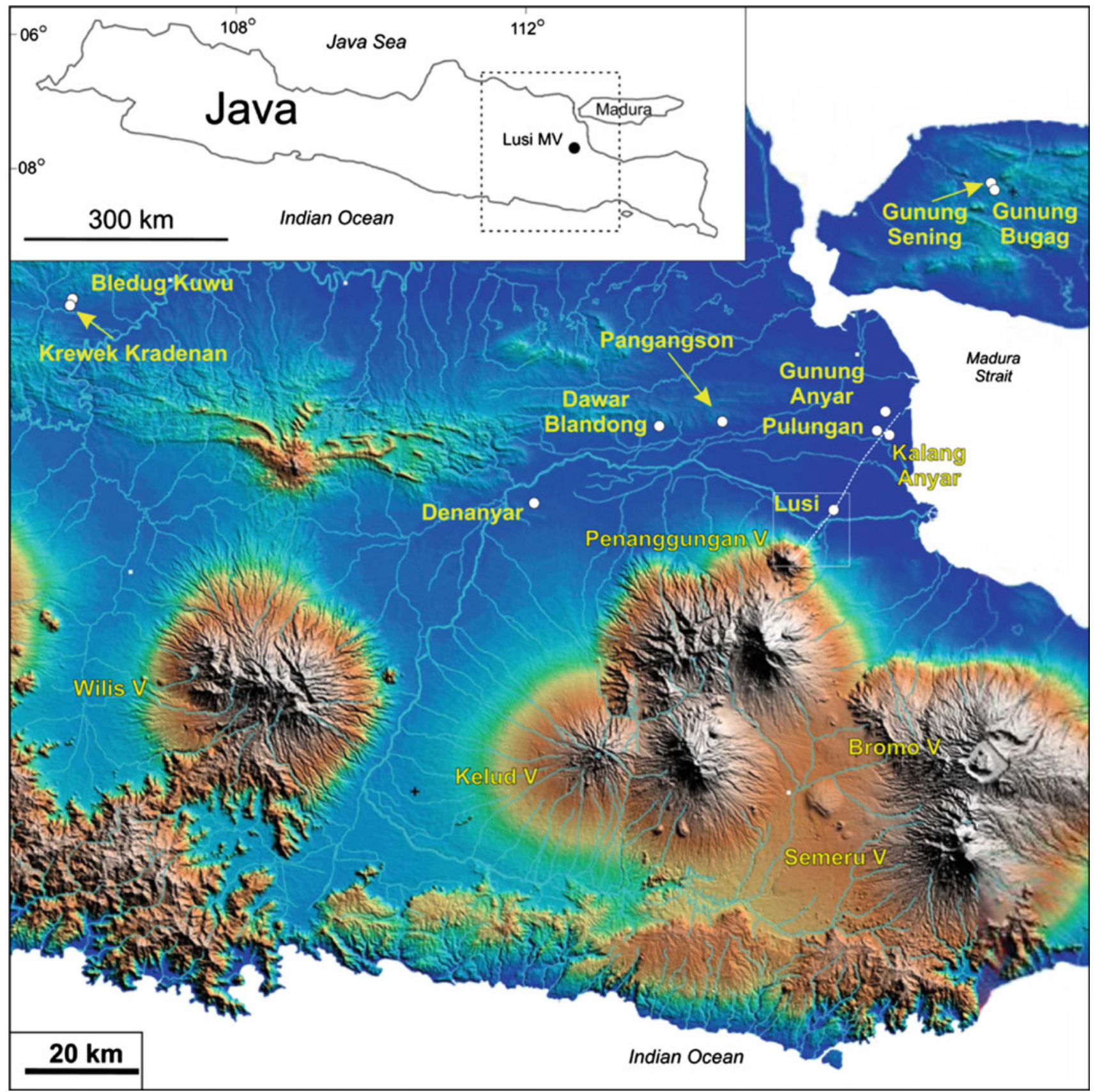

Fig. 7 Location of lusi along a fault (Mazzini et al. 2009) 


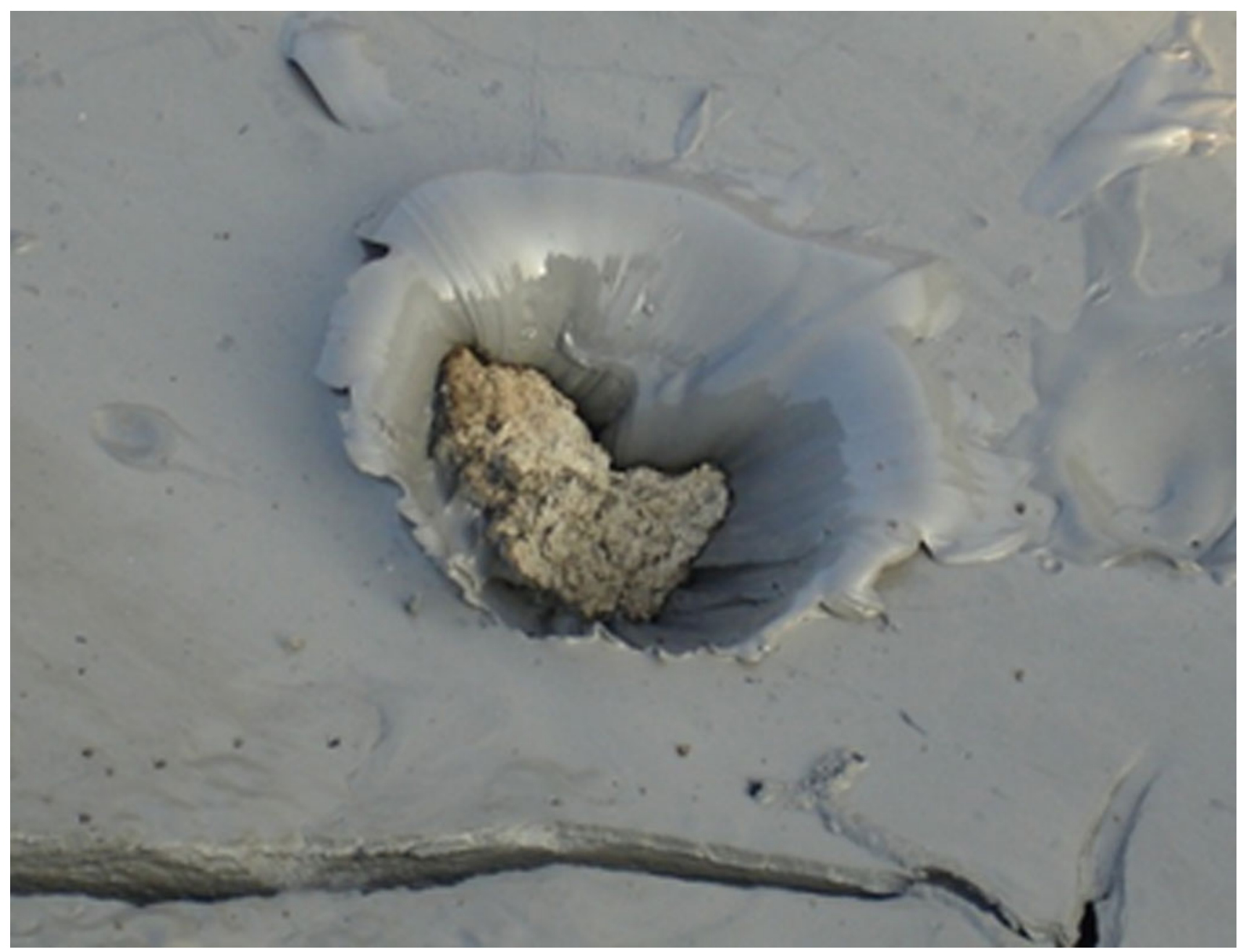

Fig. 8 The visual appearance of the wet mud (BPLS 2007)

- It can distinguish both the soil resistance and the pore pressure, hence the effective reaction of the soils can be measured and it can recognize the drained and undrained response of the soils.

- The interpretation of soil properties, although heavily reliant on empirical correlation, are accurate due to the many available measurements for comparison and justification.

- Dissipation tests can be conducted to measure the permeability and consolidation characteristics of the soils, which provides more reliable methods compared to laboratory tests.

The authors have gained a lot of experience in many projects throughout the northern coast of Jakarta and also in many places where soft soil deposits create instability during construction and the problems of long-term settlement.

The equipment consists of an electronic cone with cone tip to measure tip resistance, a friction sleeve to measure friction resistance of the soils during the course of 


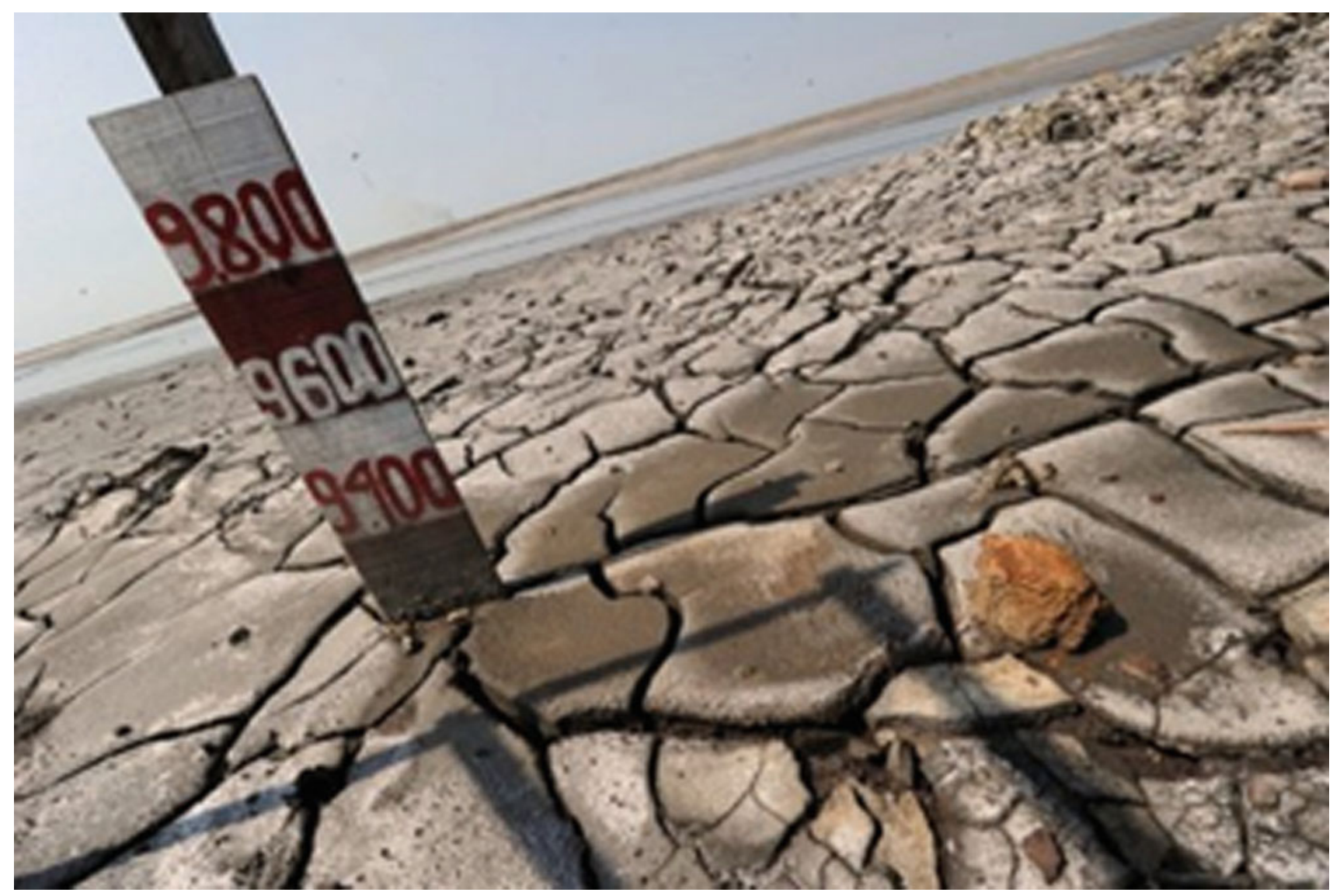

Fig. 9 Condition of the mud upon drying (hufingtonpost.com, July 22, 2013)

penetration and a pore pressure sensor to measure pore pressure - both the hydrostatic pore pressure as well as the excess pore pressure due to penetration of the cone into the ground. The measurements are conducted through cable wired to the cone and the ADU (analog digital unit) connected to the computer for data aquisition. Figure 13 shows the cone tip and the accessories for CPTu.

For reinforcement of the dyke, a series of CPTu test were conducted. Drilling soils on sites are impossible due to the existence of shallow gas and the psychological condition of the people who have suffered trauma from the drilling.
However the soil investigations used for describing the condition of the soils on site may be done by using old soil tests as well as from the new soil investigation for the construction of the dyke. Figure 14 shows the position of the CPTu tests on mud eruption site. Eight CPTus are next to the dyke and two CPTus are in the position of the mud (Fig. 15).

Figure 16 shows a typical condition of the soil next to the dyke on a mud site from CPTu tests. The soils are not only soft but there is indication that the soft foundation soils are still consolidating, judging from the value of the pore pressure ratio $\mathrm{Bq}>0.7$. The upper part is clayey silts and a water 


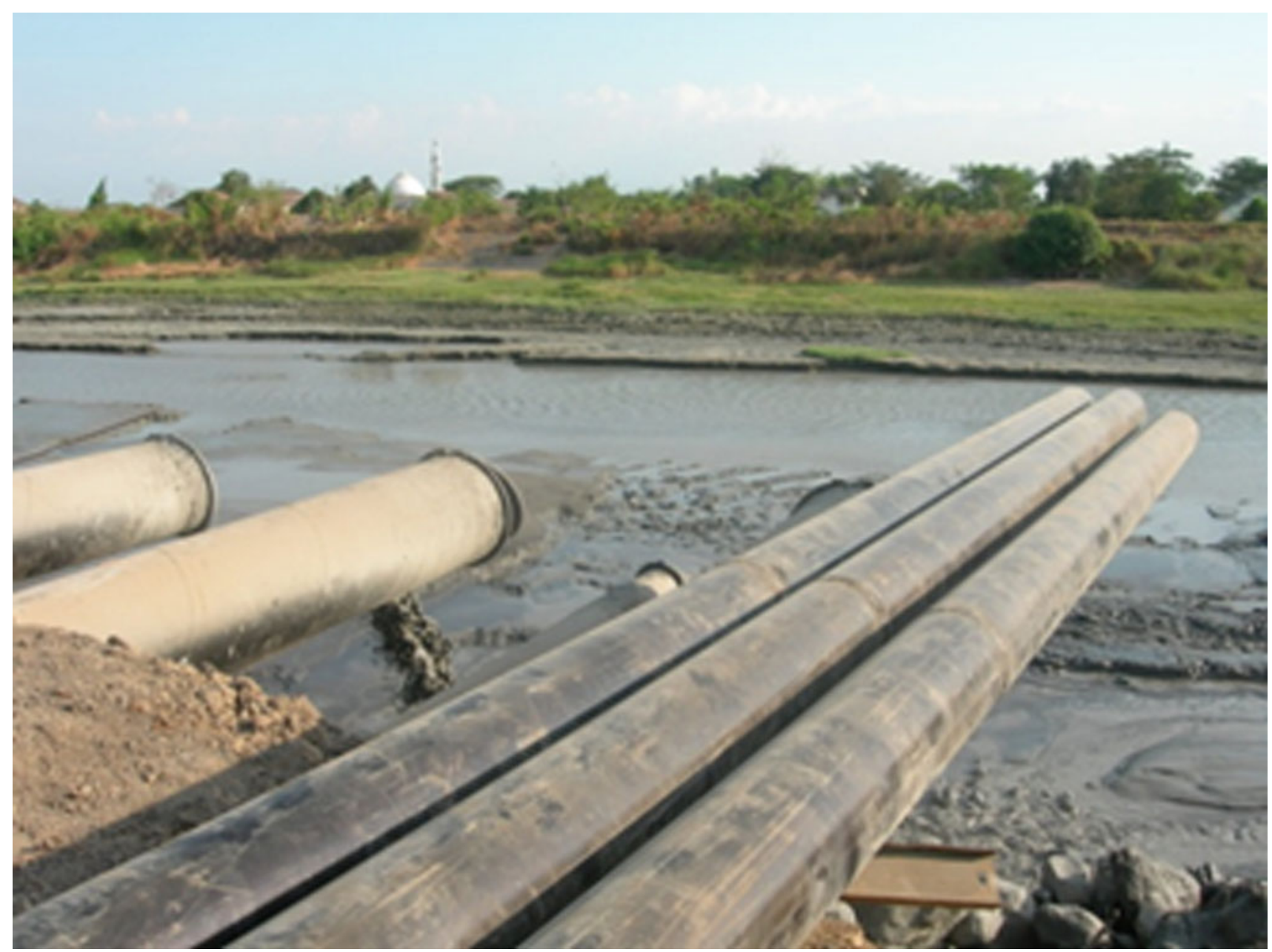

Fig. 10 Removal of the mud via the Porong River (BPLS 2007)

table is detected at about $1.0 \mathrm{~m}$ below ground surface. The variation of qc magnitude, friction ratio and pore pressure ratio show the differences in the soil behavior and soil type.

Figure 17 is the results of CPTu-09 located in the mud site. It clearly shows the thickness of the mud of $14 \mathrm{~m}$, then a thin layer of sand of about $1 \mathrm{~m}$, then the foundation soils. A test in the center of the excavation is shown in Fig. 18, where down to $28 \mathrm{~m}$ the condition is dominated fully by the mud. Further penetration was impossible due to an uplifted anchor.
It is interesting that the initial elevation of the site is about $+5.0 \mathrm{~m}$ above sea level, and the elevation of the mud at this site is about $+14.0 \mathrm{~m}$. Hence, if there is no settlement, the mud should be about $9 \mathrm{~m}$ thick. However the test shown that the mud thickness is more than $28 \mathrm{~m}$, which means that this point has settled more than $19 \mathrm{~m}$. The mud is still consolidating as shown by the high value of the Bq.

The elevation of the mud has been surveyed from 2014 until today. Figure 19 shows the results of elevation measurements in July 2015 (Sofyan 2015). 


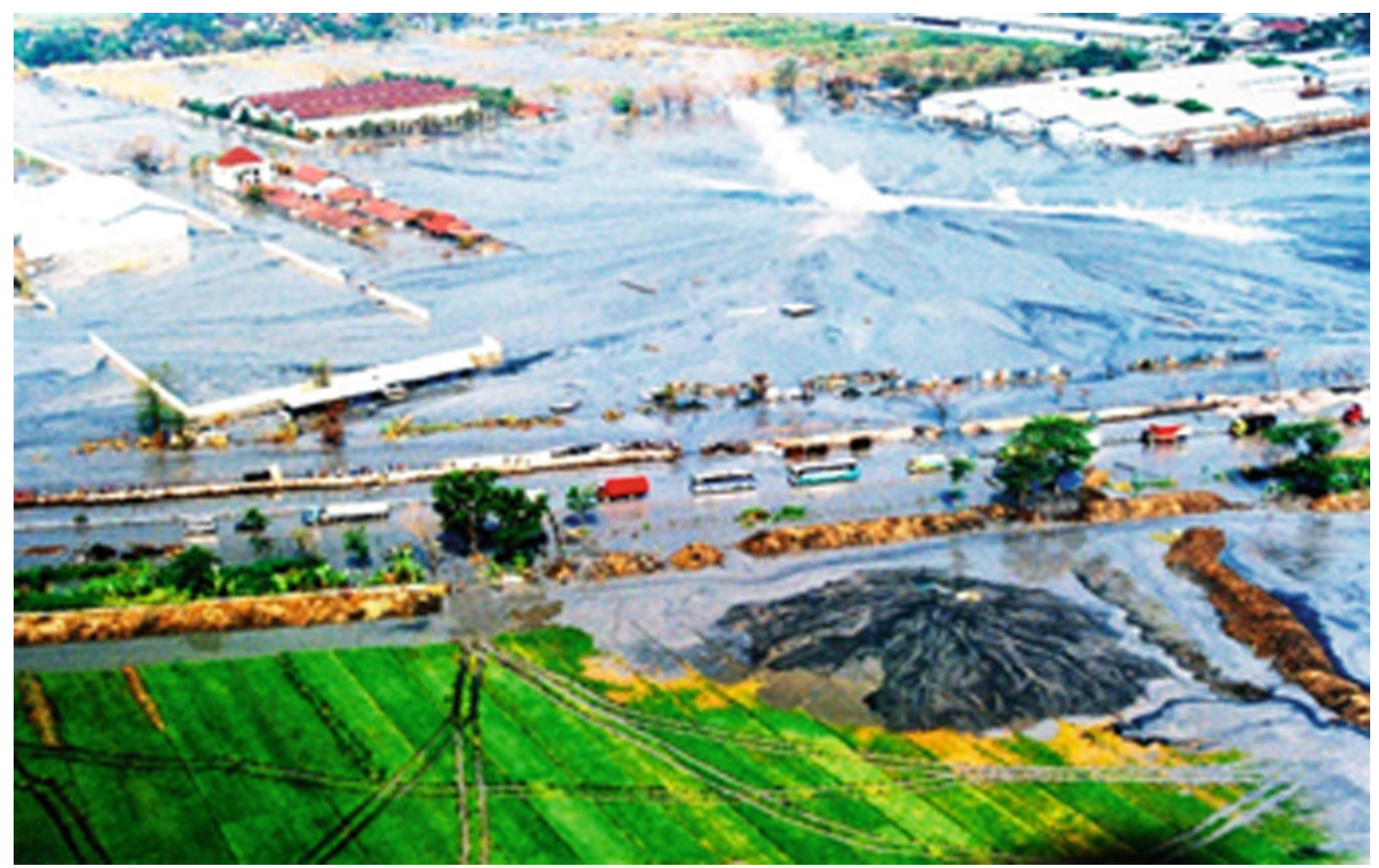

Fig. 11 Damage to area infrastructure (BPLS 2007)

\section{Stability of Dykes Used to Contain the Mud}

Due to the unknown duration of the mud eruption, the only possibility of saving human beings is by containing the mud in cells, in which the cells boundaries were dykes. Figure 20 shows the dyke boundaries in 2007. But then the boundary was kept as it is due to the possibility that the mud could be removed through the Porong River.

The dykes were constructed using gravelly sands and most were not well designed. The reason is simply because there was not sufficient time for investigation nor for compaction. Figure 21 shows emergency construction of dykes as the mud spread toward the arterial road. The compaction was conducted mainly by bulldozers and quality control was not possible. Another problem related to the dykes' safety is due to the fact that the foundation soils are mostly soft, with thicknesses from 5 to $30 \mathrm{~m}$ depth (Fig. 22).

Due to the soft foundation soils, the dykes frequently failed and move laterally, which could endanger the people in the surrounding area. Figure 23 shows maintenance of 


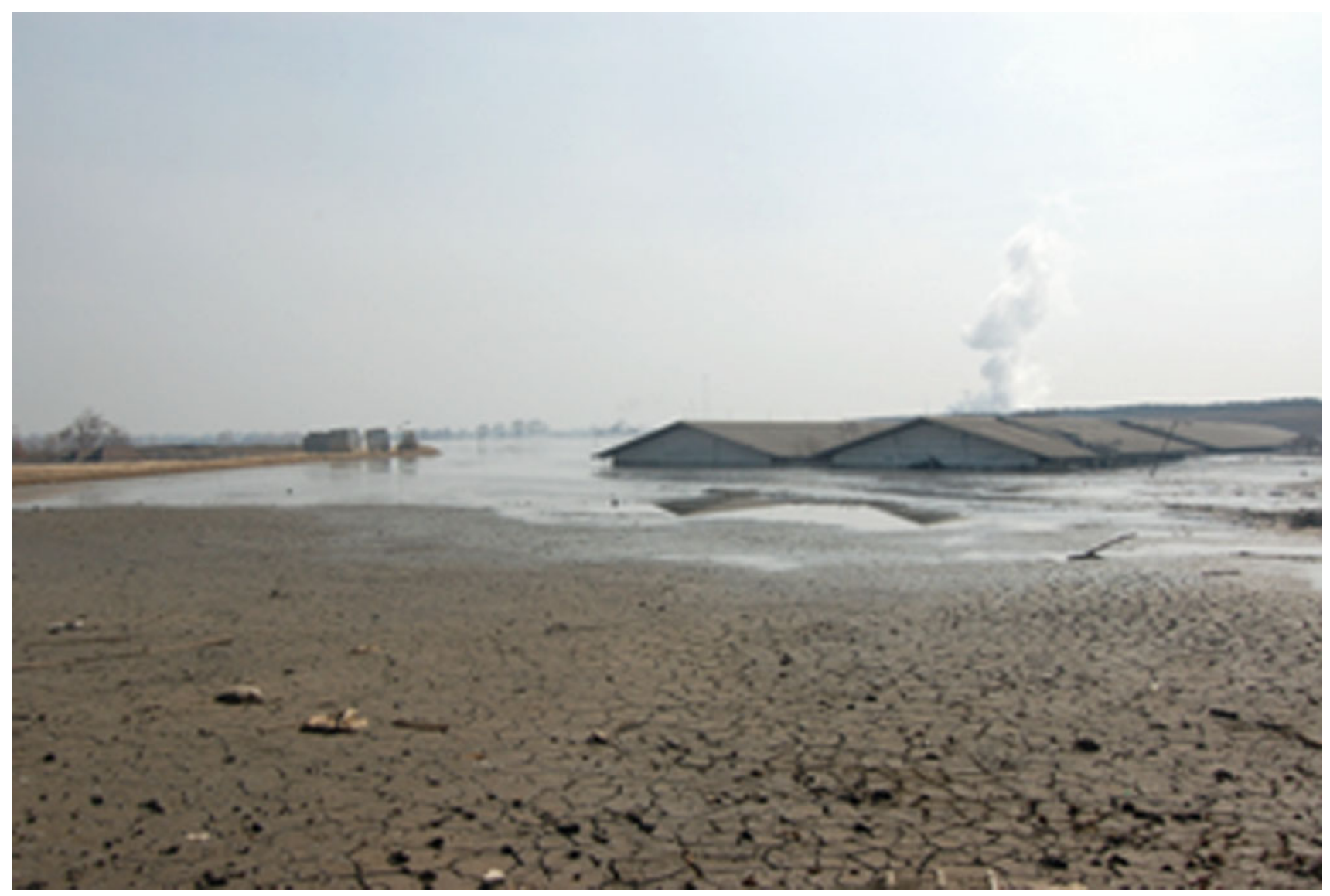

Fig. 12 Damage to houses in the muddy flood (BPLS 2007)

dykes in the center, which now has reached $25 \mathrm{~m}$ high due to the continuous settlement. As the dykes became higher, stability has become particular concern. To reduce the amount of fill, large sandbags have been used in the fill embankment.

A study was conducted by Augustawijaya et al. (2012) to analyse the stability of the dykes. The particular location for his study was the dyke at number 10D. The results show that the stability is marginal.

In August 22, 2010, a particular accident accompanied a sudden flood landslide (like a cold lahar) in the south east, a phenomena that has occured in debris flows and sediment gravity flows (Hardy Prasetyo 2010). In a matter of minutes, three dredgers that were operating there were driven as far as $200 \mathrm{~m}$ from their original position (Figs. 24 and 25).

\section{Land Subsidence and Settlement Problems}

At the center of the vent, the land sank because so much water and mud from beneath the ground was erupted. To maintain the height of the dykes, large sandbags were used. 


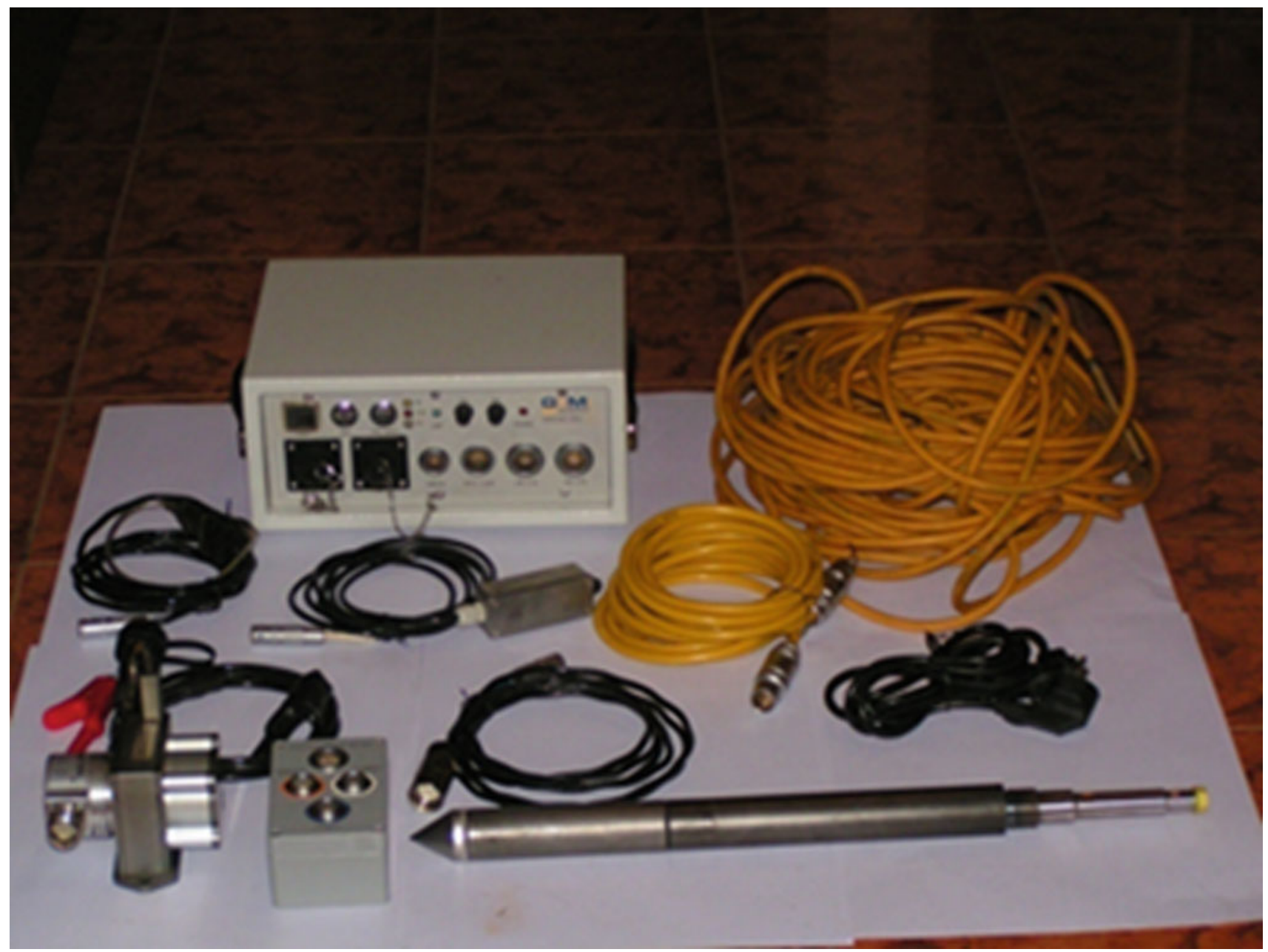

Fig. 13 CPTu equipment for the research of lusi

But also the surrounding land shows signs of settlement, and based on measurements, the affected area has a radius of $1.5 \mathrm{~km}$. Pressure in the pond has caused settlement of the surrounding area, including serious settlement along the dykes. Feasibility Study of Settlement (TKKP) from ITS since November 2009 recorded settlement of the order of $10 \mathrm{~cm}$ per month. The average drop of settlement within a period of six month may reach $150 \mathrm{~cm}$. On the other hand, land in the western and Jatirejo Siring Village has been raised by about $1.0-3.0 \mathrm{~m}$. This could be due to deep sliding. 


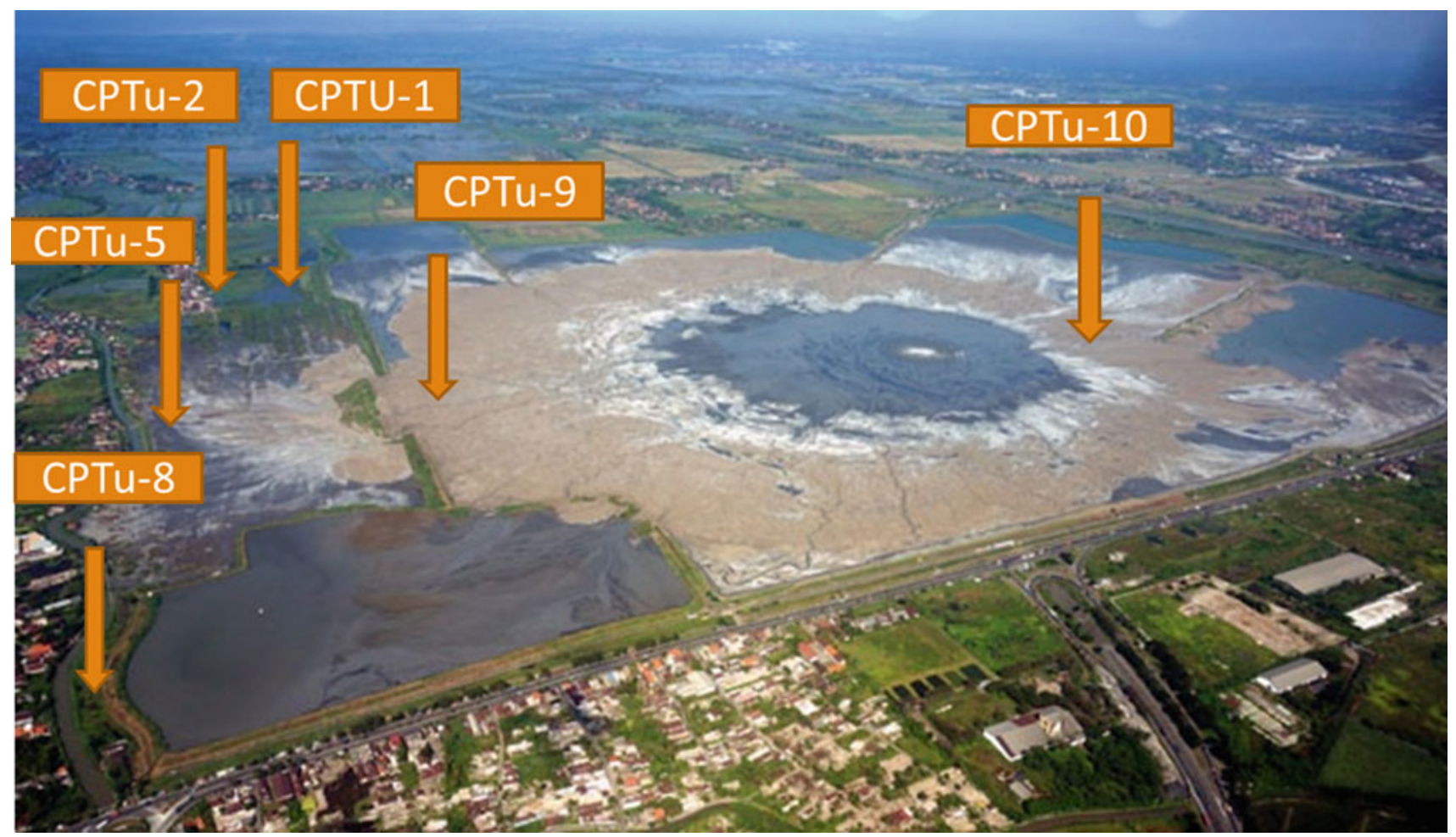

Fig. 14 Location of CPTu tests

\section{Mitigation and Implementation}

There are a number of geotechnical problems that must be solved, including the safety of the dykes, settlement or land subsidence, and risk of overflow. For dyke safety, it should be monitored visually as well as using instruments such as settlement points, inclinometers and pizometers. Those instruments will serve to measure the performance of the dyke, as well as act as a warning system if the dyke is not stable.

For subsidence it is necessary continuously monitor a large area. The land subsidence may damage houses and hence the boundary of the area that is influenced shall be relocated. For transportation toward Malang, a new arterial road has been completed. The relocation is to west side, assuming that the east side has lower elevation. 


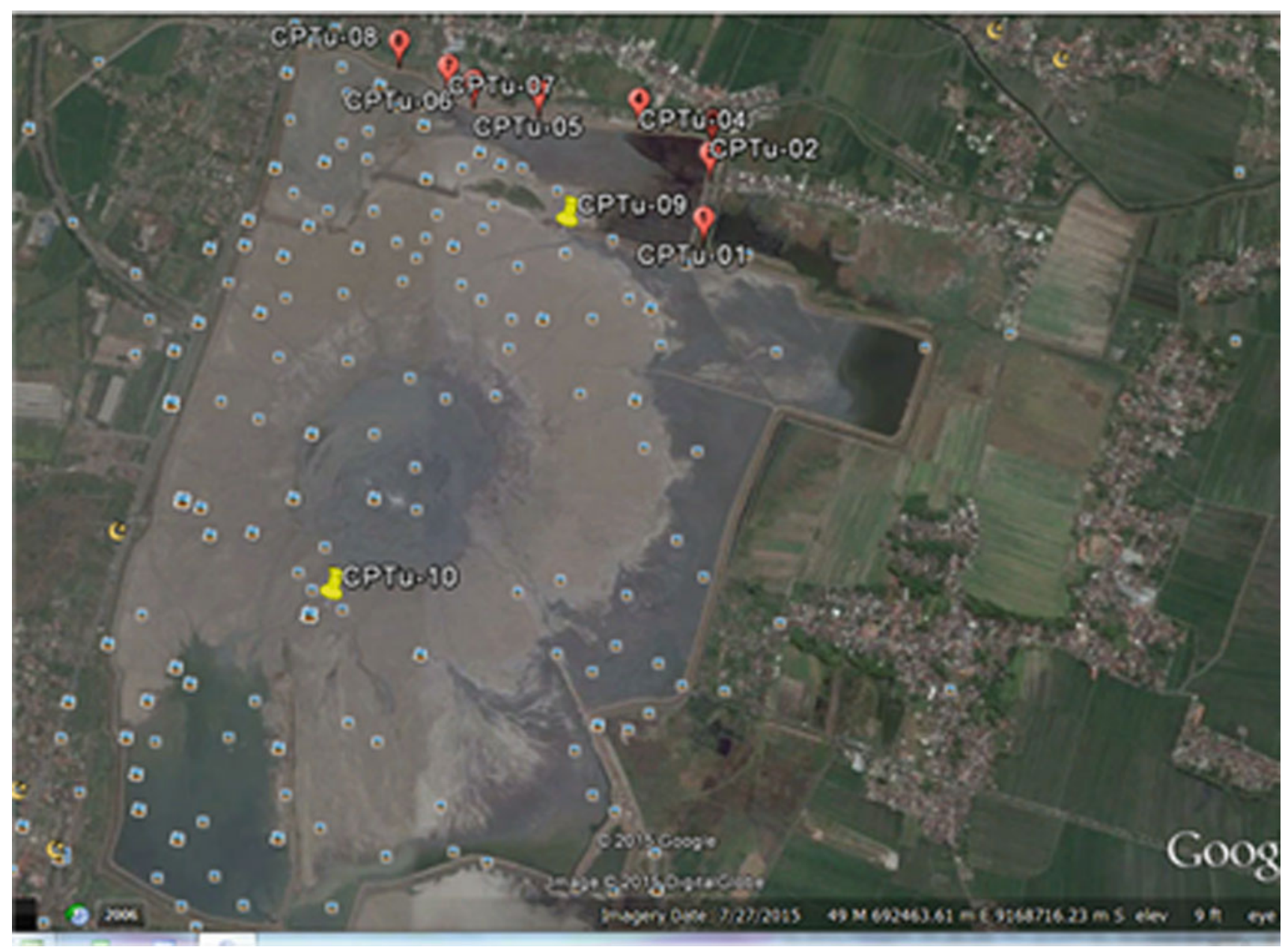

Fig. 15 Location of the CPTus tests on mud sites

\section{Conclusions}

Based on the study, some conclusions are made:

- The soil conditions underneath the mud eruption and the area of mud containment are generally very soft. This condition causes serious problems with stability and subsidence. In most cases, the soils are still consolidating and are sensitive to disturbance. Additional loading will be very dangerous and may trigger dyke failures.

- The first year of the study has been basically to identify the geotechnical problems of the mud eruption disaster.
We need more detailed studies of awareness and preparedness.

- CPTu is the best tool to study the mud conditions, as well as the foundation soils.

- There is a chance for improvement due to the significant decrease in mud discharge. Reclamation may be proposed. At least in part it will be possible to compress the mud into a stronger layer along the periphery of the dyke.

- The mud discharge to Porong River may cause long-term problems due to sedimentation along the river and in the estuary area. 


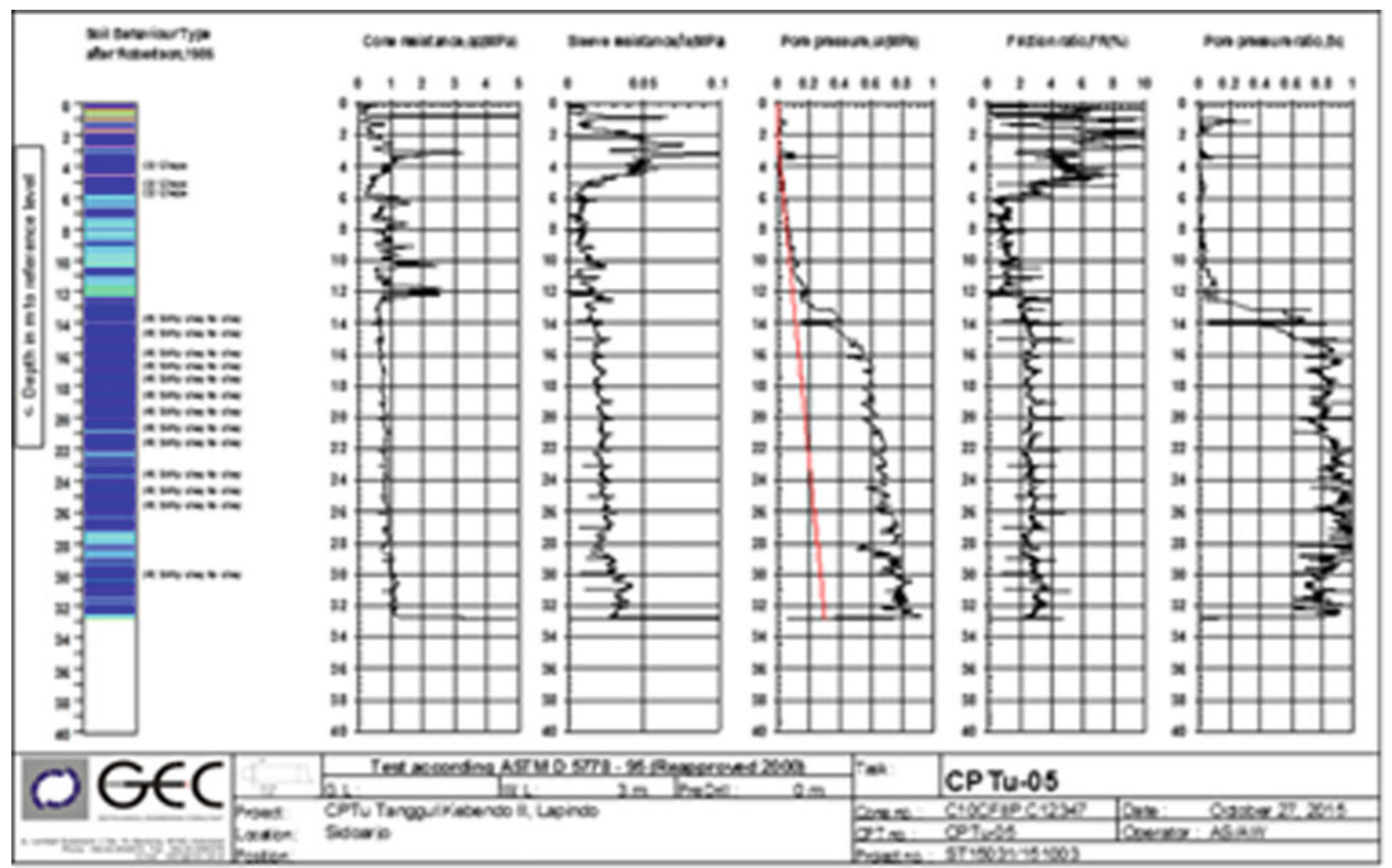

Fig. 16 CPTu tests on the outer side of the dyke

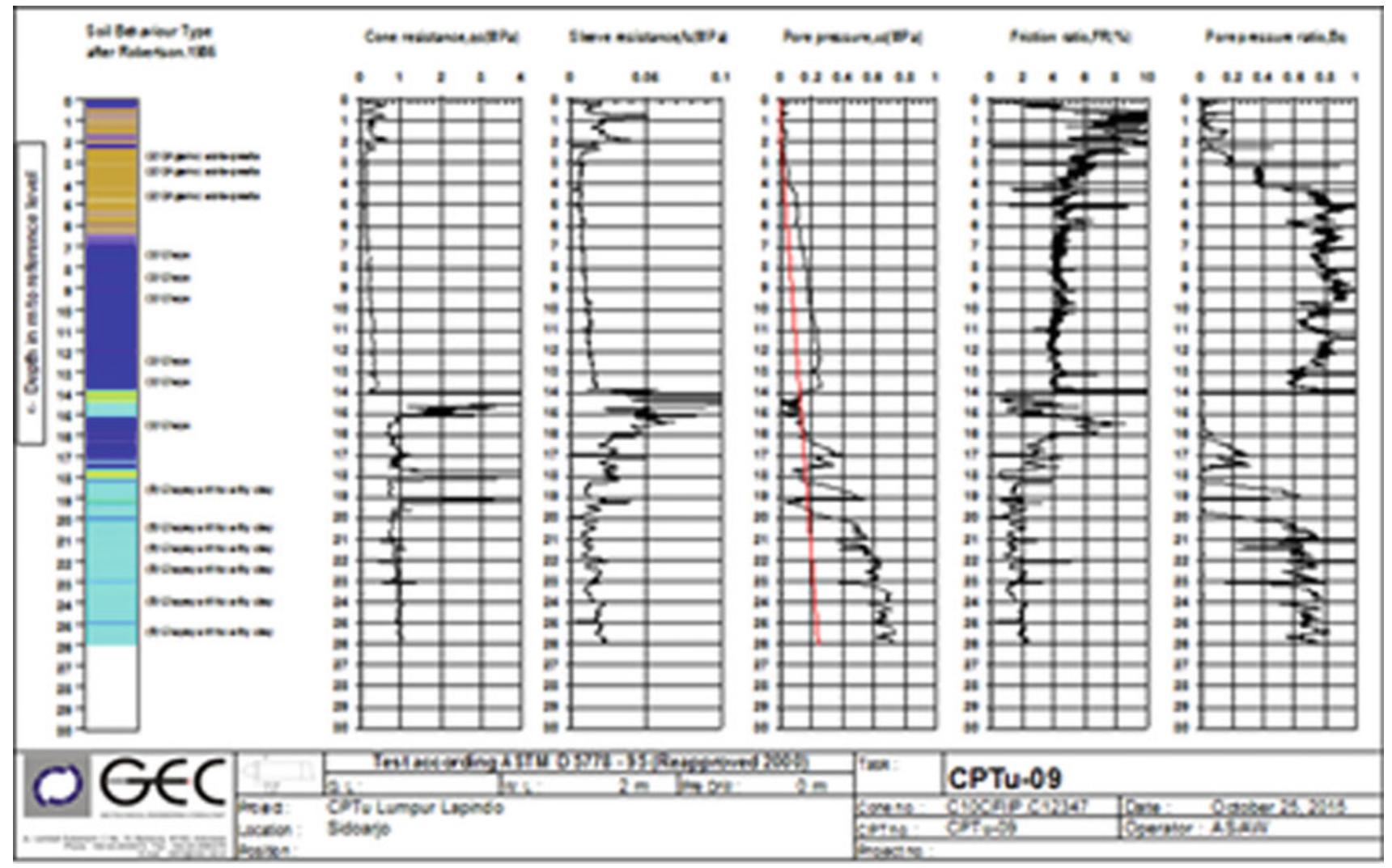

Fig. $17 \mathrm{CPTu}-09$ located in the mud eruption site 


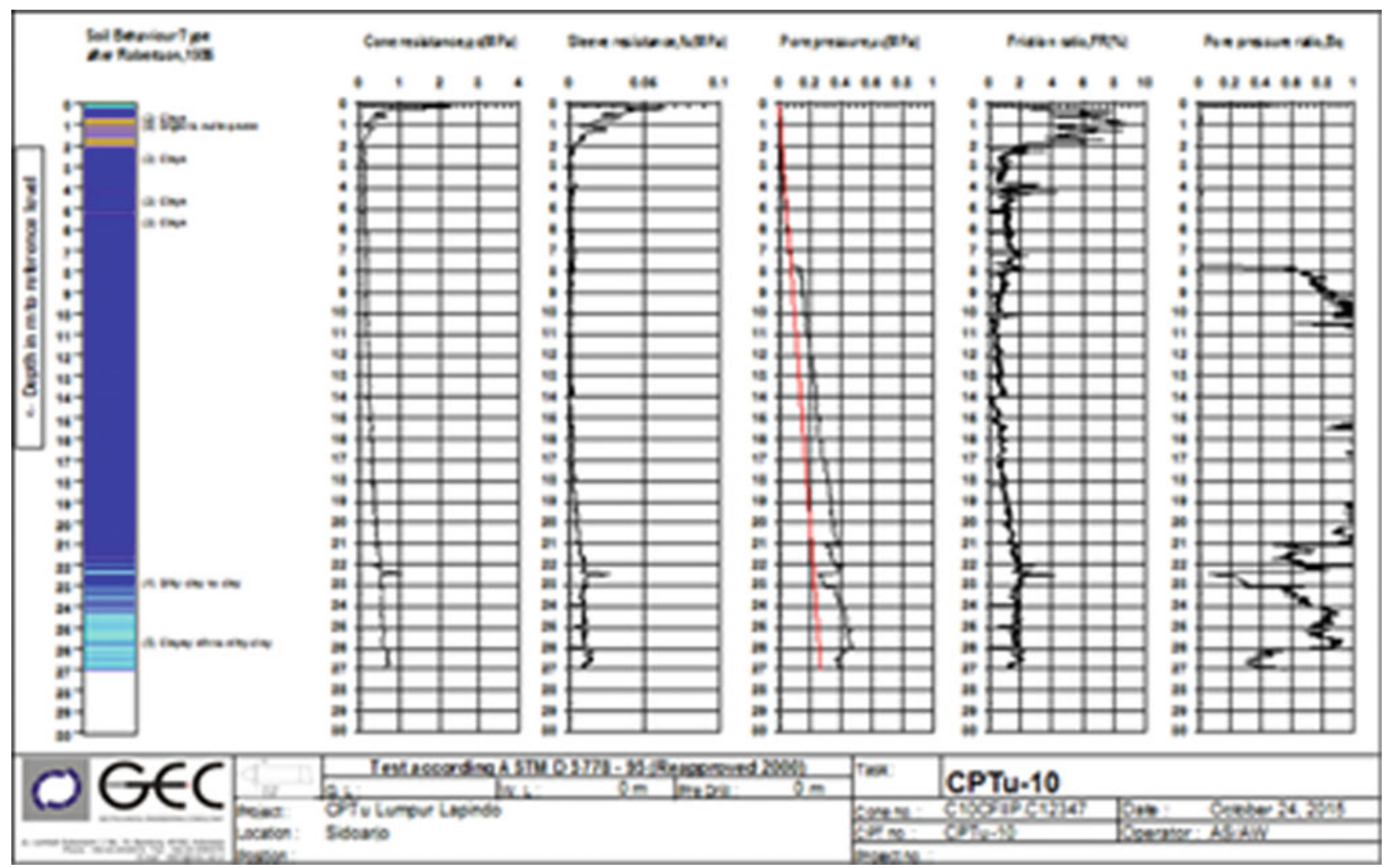

Fig. $18 \mathrm{CPTu}$ at the center of the mud eruption

It is suggested to install geotechnical monitoring system which will provide information on the performance of the dykes.
Acknowledgements The authors appreciate the assistance of Lembaga Penelitian dan Pengabdian Masyarakat (LPPM) of Parahyangan Catholic University for providing funds to do work on this research and to BPLS and engineers of PT GEC for providing information and data. 


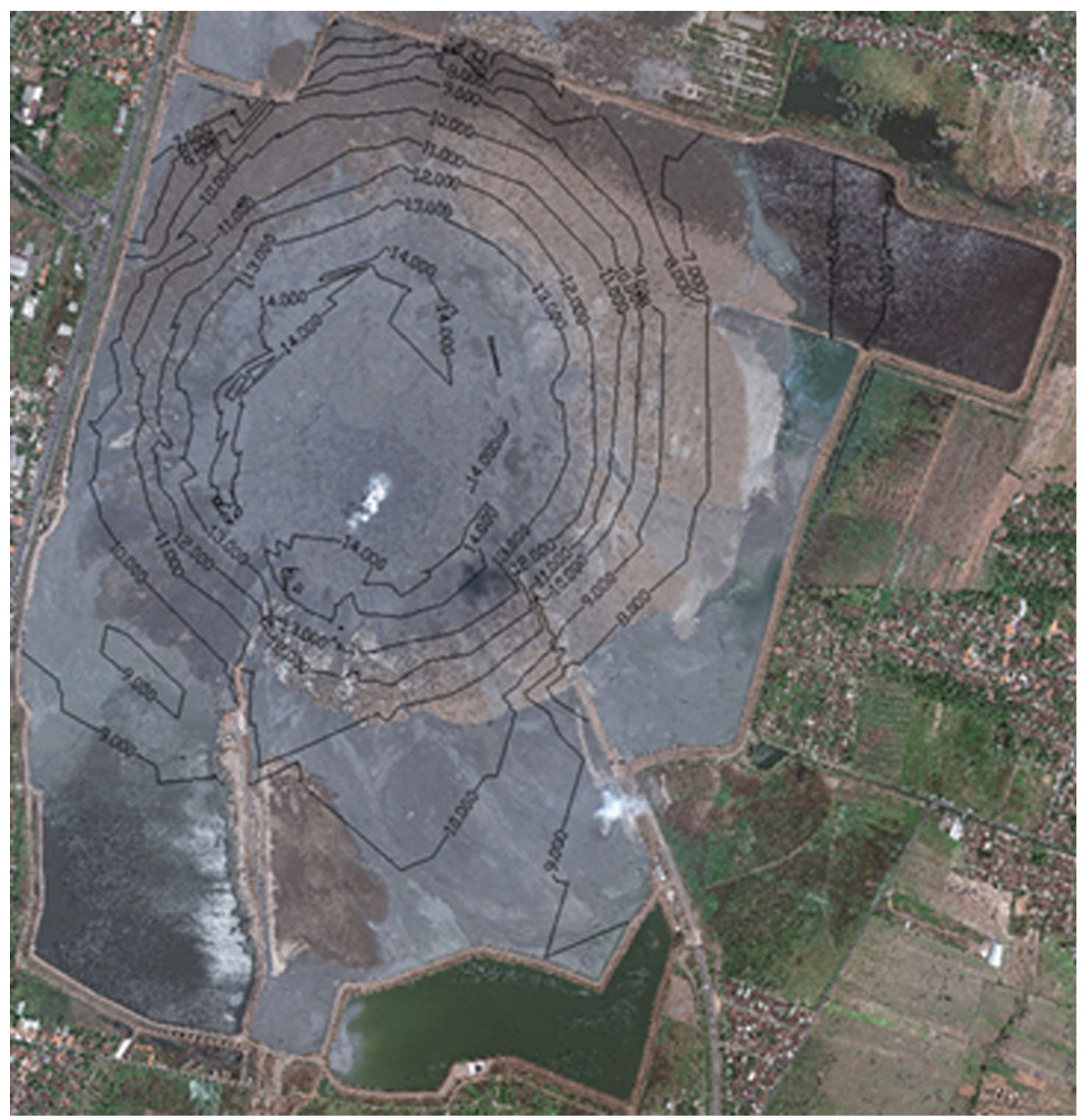

Fig. 19 Survey elevation of the mud (Sofyan 2015) 


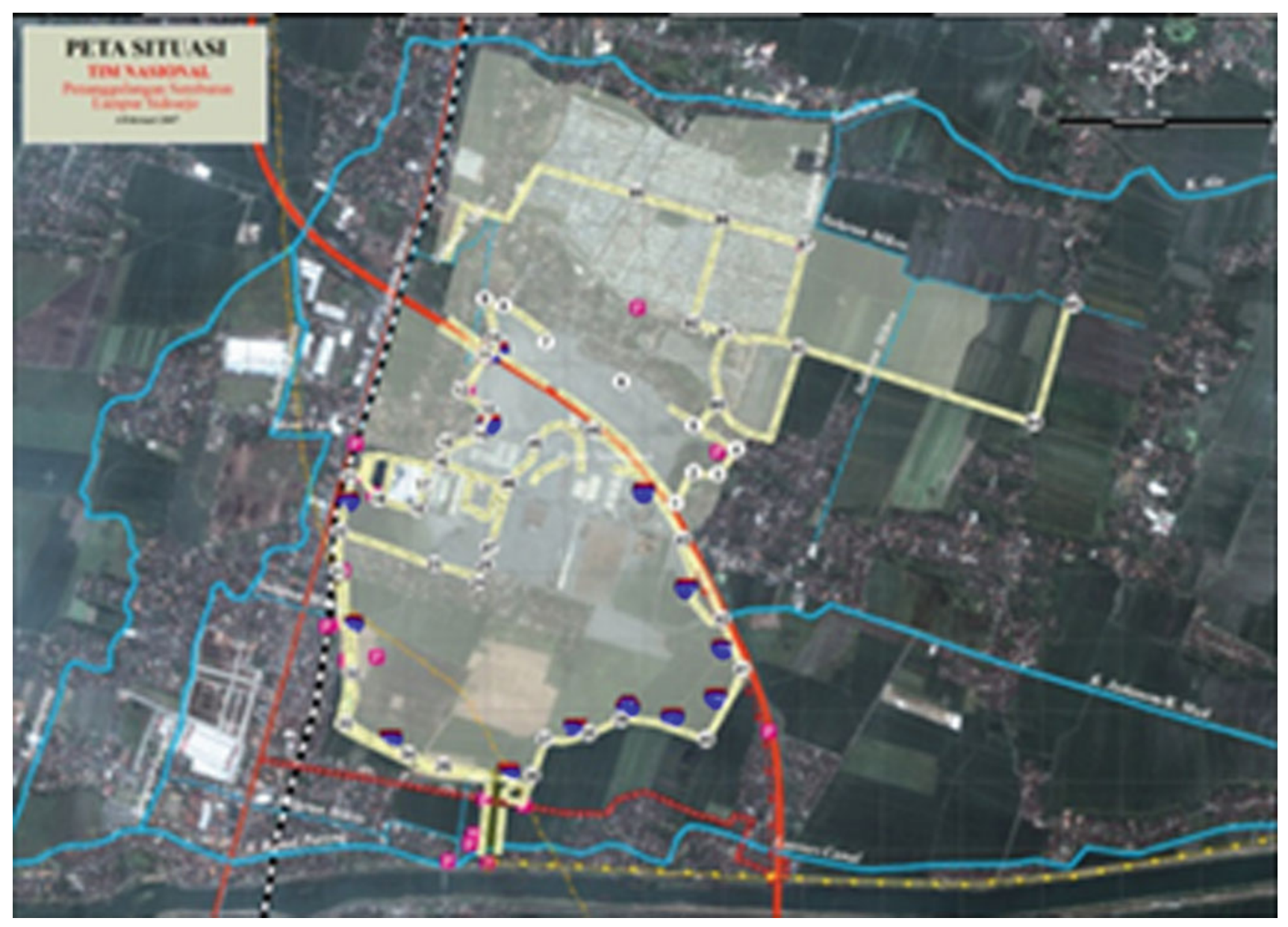

Fig. 20 Boundaries of cells to contain the mud (Tim Nasional 2007) 


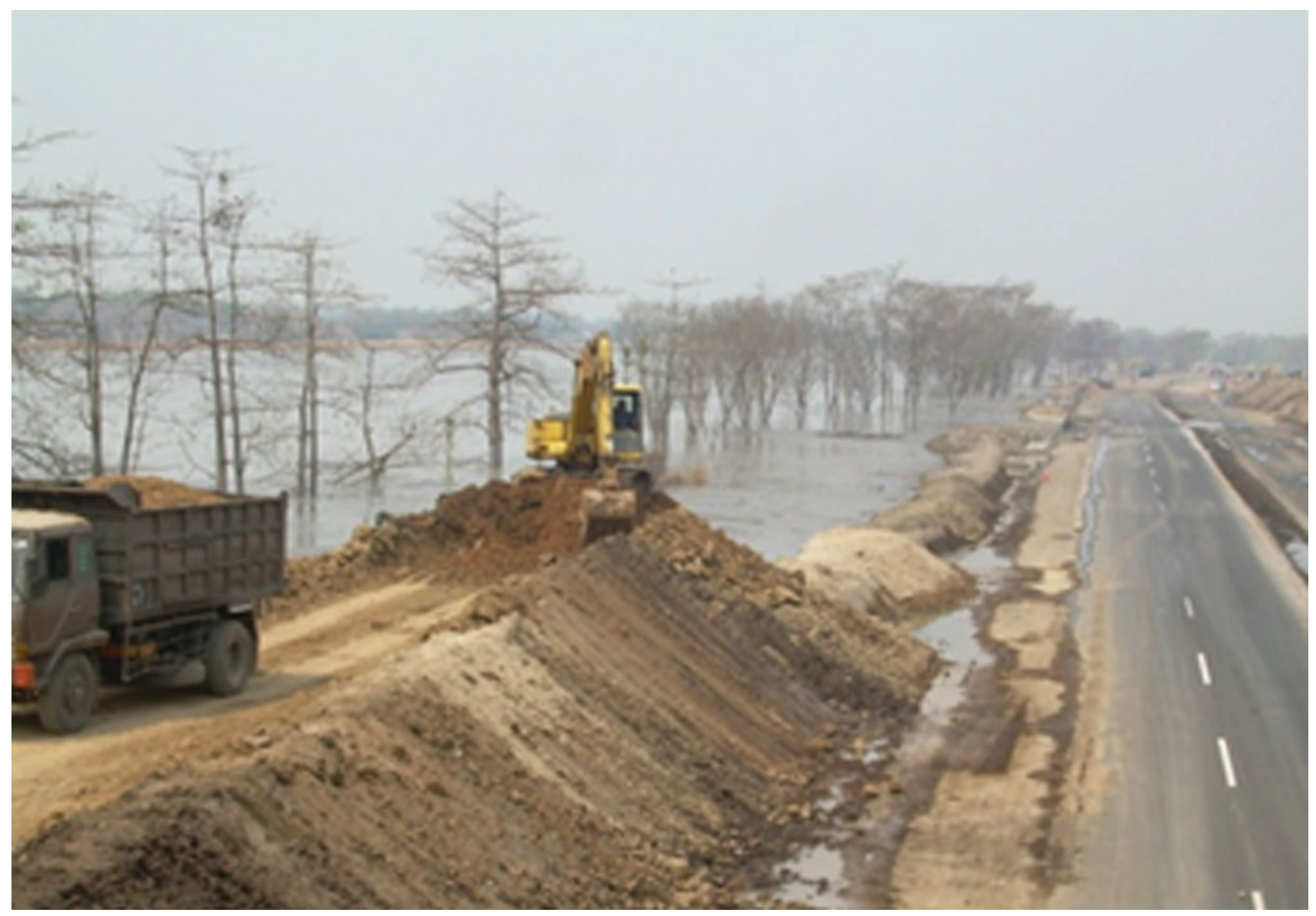

Fig. 21 Construction of permanent dykes (BPLS 2007)

Fig. 22 The heights of dykes used as boundaries of cells

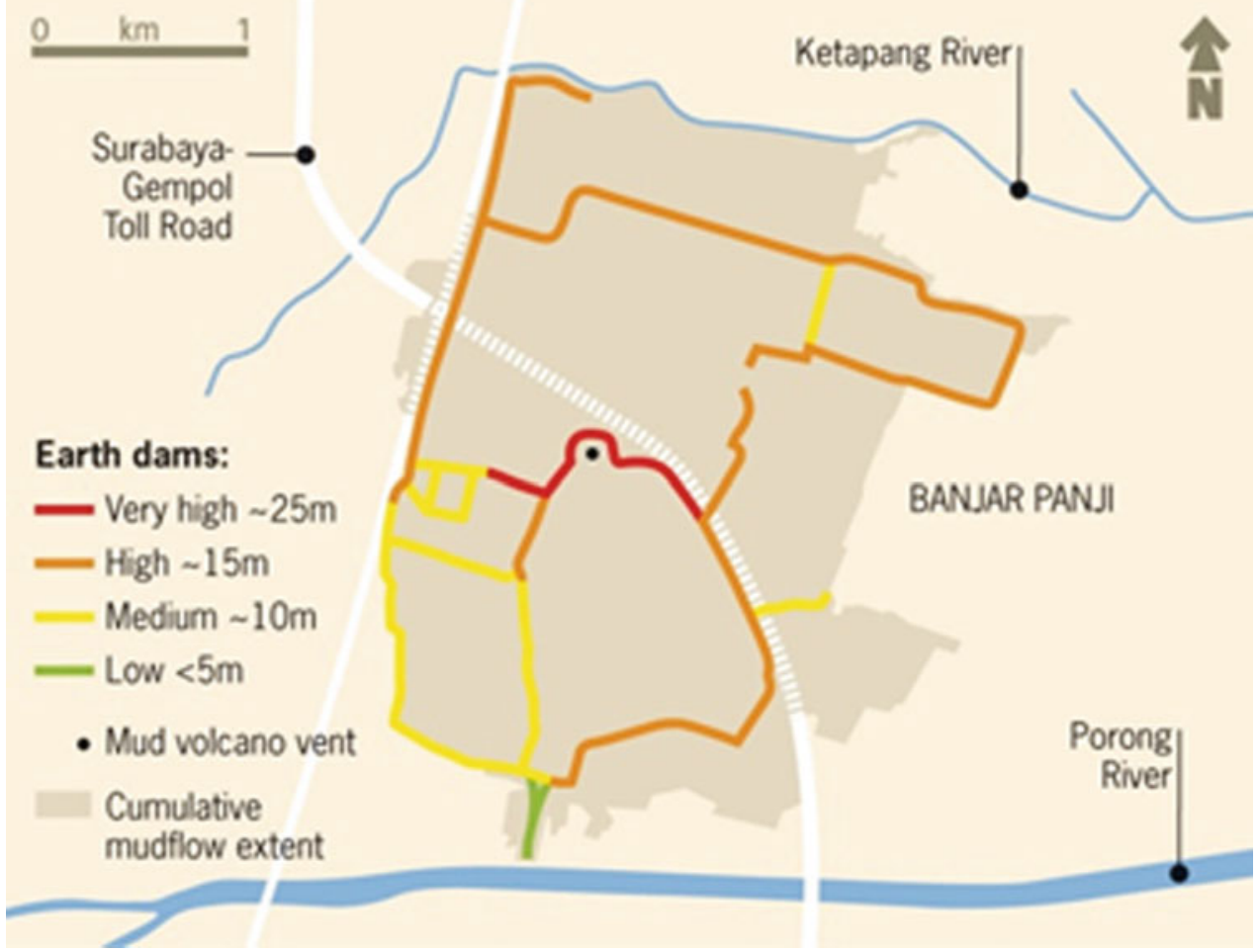




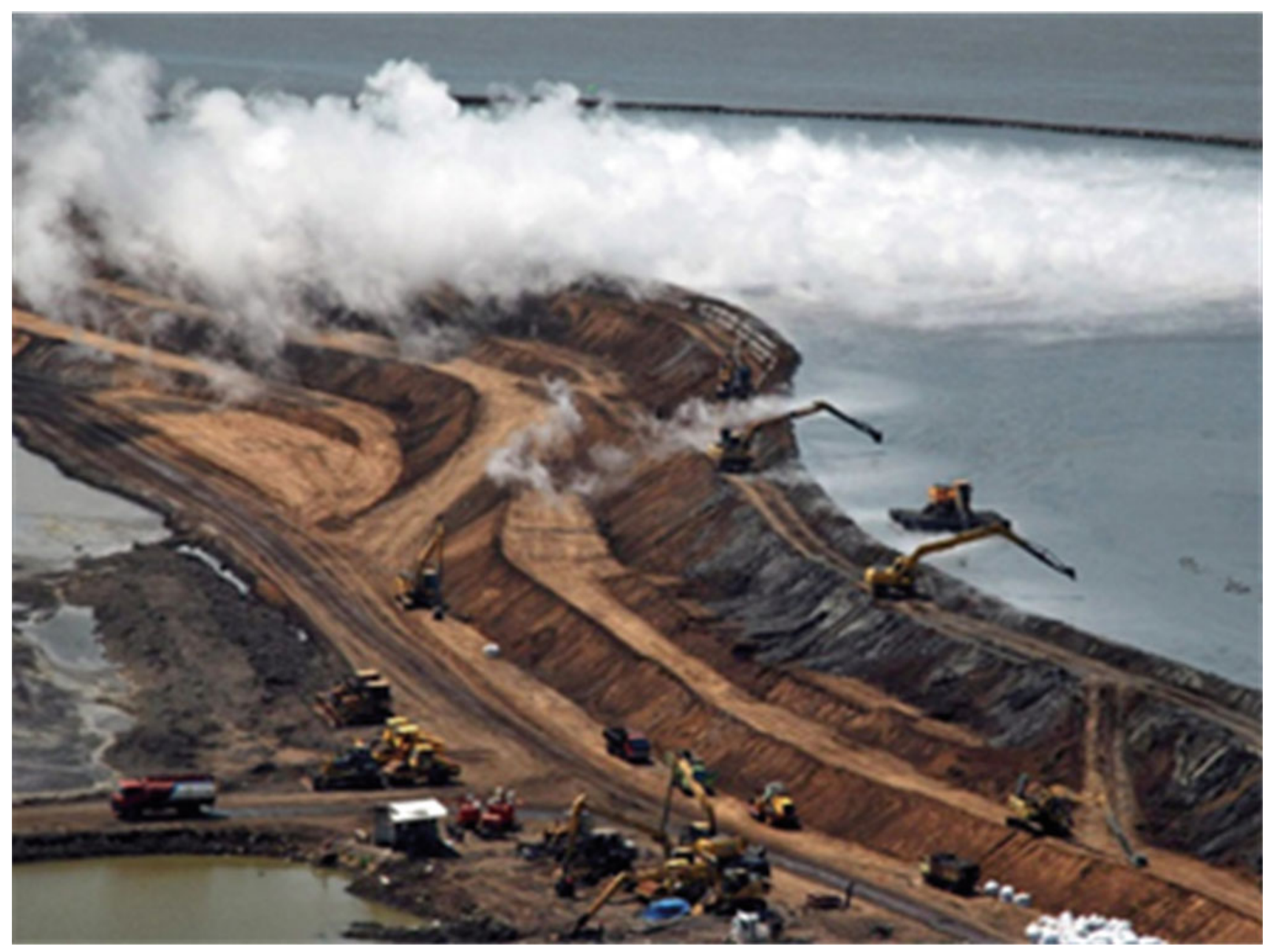

Fig. 23 Maintenance of dykes 


\section{STRATBagR A CNons setion}

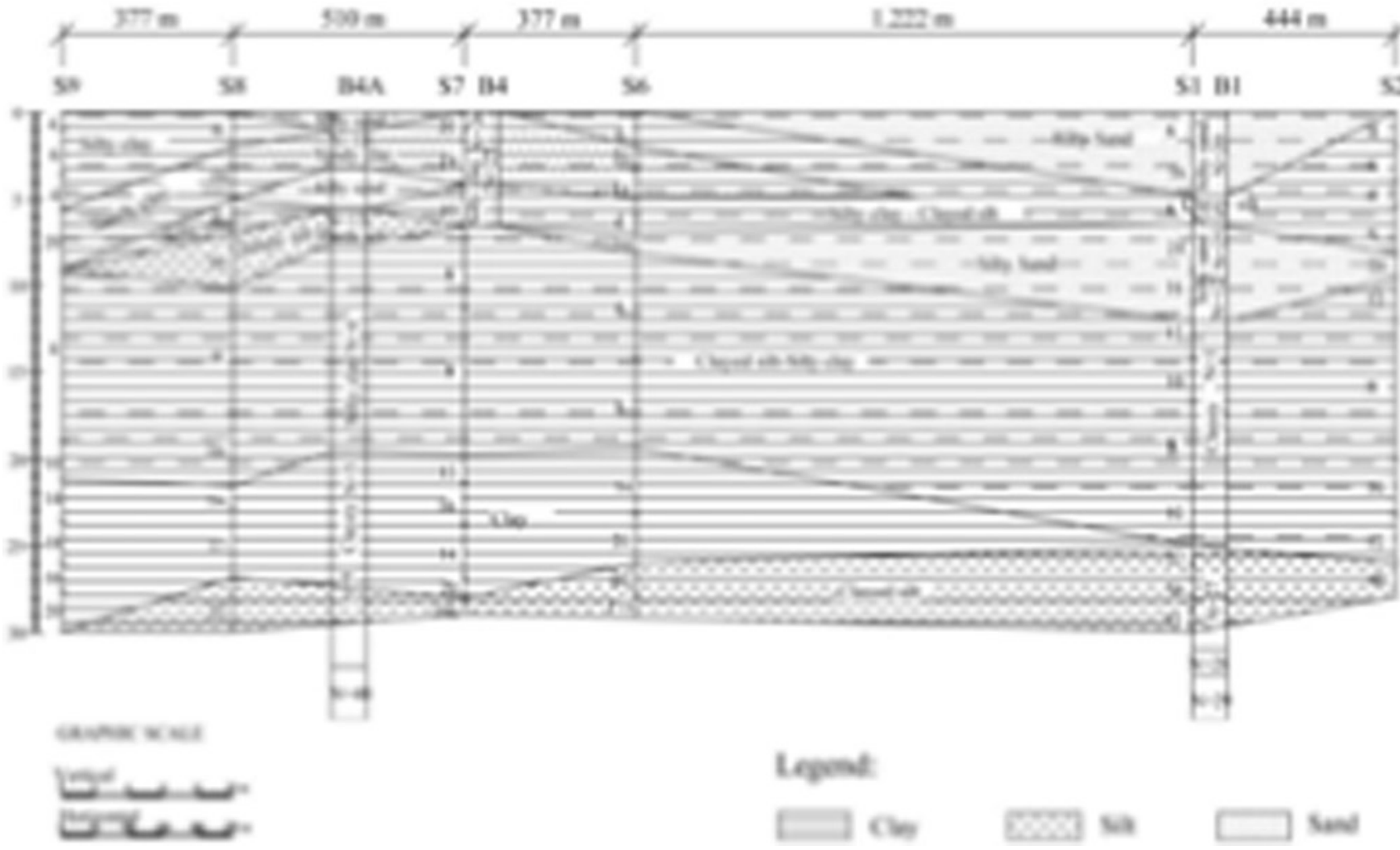

Fig. 24 Geotechnical cross section of foundation soils (Augustawijaya et al. 2012)

Fig. 25 Cross section of dykes (Augustawidjaja 2012)

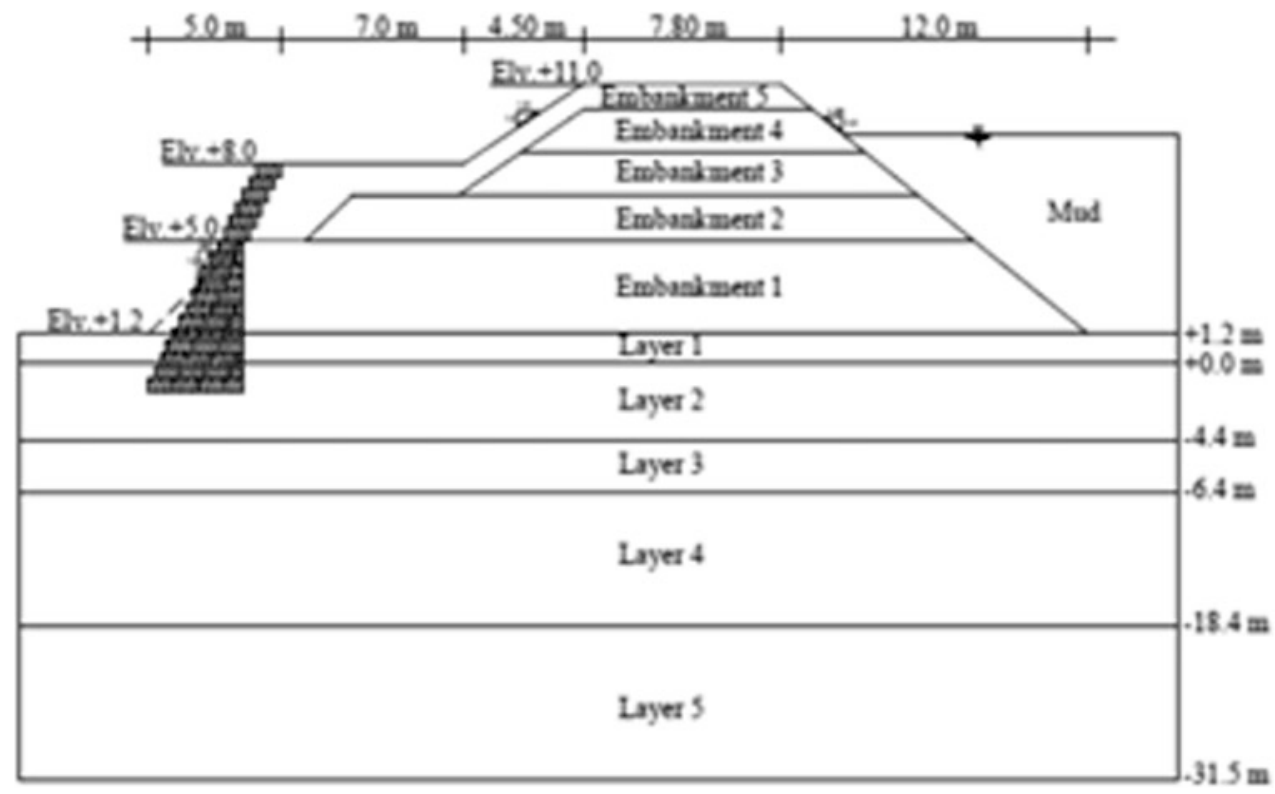




\section{References}

Agustawijaya DS, Sukandi (2012) The stability analysis of the Lusi mud volcano embankment dams using FEM with special reference to the dam point P10D. Civ Eng Dimension 14(2):100-109

BPLS (Badan Penangulangan Lumpur Sidoardjo) (2007) Personal communication with Mr. Sofyan

Boston.com (2008) Sidoardjo's man-made mud volcano

GEC PT (2009) Soil investigation report using CPTU for the alternative by pass road at Porong (Report)

Guntoro A (2011) Understanding the origin of Sidoardjo mud volcano in relation to longevity estimation based on regional study and seismic interpretation. Lectures at Geological Department Trisakti University, Jakarta

Kompas (2010) Lapindo mud resulted in building fracture, Surabaya, 22 June 2010

Open Access This chapter is licensed under the terms of the Creative Commons Attribution 4.0 International License (http:/l creativecommons.org/licenses/by/4.0/), which permits use, sharing, adaptation, distribution and reproduction in any medium or format, as long as you give appropriate credit to the original author(s) and the source, provide a link to the Creative Commons license and indicate if changes were made.
Rahardjo PP (2011) Geotechnical aspect of Sidoardjo mud eruption (in Indonesian), report, Center for Infrastructures and Urban Development, Parahyangan Catholic University

Rahardjo PP (2015) Geotechnical aspect of mud eruption disaster in East Java. In: Proceeding 19th Asian regional conference on soil mechanics and foundation engineering, Fukuoka, Japan

Mazzini A, Nermoen A, Krotkiewski M, Podladchikov S, Planke S, Svensen H (2009) Strike-slip faulting as a trigger mechanism for overpressure release through piercement structures: implications for the lusi mud volcano, Indonesia. Mar Petrol Geol 26(9):1751-1765

Sofyan (2015) Report on the latest situation of Lumpur Sidoardjo. In: Proceedings international conference on landslides and slope stability, Bali

Soleman AR (2012) Karakterisasi Tanah Lempung Lunak di Porong Sidoardjo berdasarkan Uji CPTu dan Uji Laboratorium, tesis Magister. Universitas Katolik Parahyangan, Bandung

Wayman E (2011) The World's Muddiest disaster, Smithsonian.com, 2 Dec 2011
The images or other third party material in this chapter are included in the chapter's Creative Commons license, unless indicated otherwise in a credit line to the material. If material is not included in the chapter's Creative Commons license and your intended use is not permitted by statutory regulation or exceeds the permitted use, you will need to obtain permission directly from the copyright holder. 